\title{
English Is Not All That Matters in the Education of Secondary Multilingual Learners and Their Teachers
}

\author{
Kara Mitchell \\ University of Colorado-Denver
}

U. S. A.

ABSTRACT: Utilizing the critical race theory (CRT) construct of majoritarian stories and the already identified story of English-is-all-that-matters in the education of multilingual learners and their teachers, this study illustrates the influence of this powerful narrative in classroom practice. By promoting English-only instruction, maintaining a limited perspective of what it means to know English, and treating multilingual learners as if they were monolingual, this study demonstrates that multilingual learners' educational opportunities are being limited through a persistent and unhelpful overemphasis on English.

Theoretical Framework: Critical Race Theory (CRT) Research Design

A Majoritarian Story: English is All that Matters Conclusion: English is NOT All that Matters

Notes

References

In the current policy context in the Unites States, bilingualism is not viewed as a resource. In fact, most states in the United States identify the subgroup of multilingual learners only in terms of their "Limited English Proficiency" (LEP) or as "English Language Learners" (ELL) and otherwise overlook the population in policy and data analyses. A multilingual learner is a student whose daily lived reality necessitates the negotiation of two or more languages. In the United States, one of those languages is English, and the students whom I call "multilingual learners" are at all stages of language development in regards to both English and their heritage languages. Brisk (2006) contends that multilingual learners are more than simply the sum of two monolinguals. They are "influenced by a dynamic cross-cultural experience, rather than rigid cultural stereotypes," and understanding this "is vital for designing school policy, classroom practices, and assessment procedures" ( $p$. 3).

However, in current policy and practice, multilingual learners are either positioned as English deficient or entirely invisible, especially once a multilingual learner reaches a certain level of English proficiency. For instance, the No Child Left Behind federally mandated data reporting regarding the performance of multilingual learners labeled as ELL on state standardized tests truly only exposes the fact that students who are not yet proficient in English struggle to 
succeed in a schooling system that is often only in English. However, these same data are frequently used to suggest widespread failure on behalf of multilingual learners and their teachers (Menken, 2010).

It is problematic that students who are by definition "not currently able to perform ordinary classroom work in English" (M.G.L.c.71A§2) are expected to meet competency determinations, pass high-stakes tests, and complete the coursework necessary for graduation, all in English. Constructing the multilingual learner population in terms of English proficiency and therefore either situating them as academic failures or invisible in policy and practice institutionalizes discrimination. Where so many students are positioned within the system only in terms of their deficit and where others are completely invisible within it because they have reached relatively higher levels of English proficiency, inequity appears inevitable for multilingual learners and their teachers in current educational processes. Due to such systemic inequity, contemporary and historical institutionalized racism and linguicism, or language-based discrimination (García, 2009; Phillipson, 1992), appear to play significant roles in the current context and require further attention.

This "instrumental case study" (Stake, 2000) of an in-depth longitudinal qualitative dataset of one teacher candidate/novice teacher was designed to explore the outcomes at the classroom level of systems, policies, and practices that focus heavily on English for multilingual learners and their teachers. Results of this study suggest that current systems, policies, and practices support multilingual learners to reach a certain, insufficient level of English proficiency but, once this level is attained, leave multilingual learners largely invisible and abandoned in the system, as well as set up for failure. These findings suggest a need to re-conceptualize and re-position multilingual students as multilingual rather than English-deficient in our educational system in order to ensure a quality education for students across all content areas, grade levels, and individual levels of English language proficiency.

To support this analysis, first, an overview of critical race theory, the theoretical framework guiding this research, is provided. Next, the research methodology, data collection, and data analysis are discussed. Then, the findings of this instrumental case study are presented, as well as the implications for policymakers, teachers, and teacher educators in terms of supporting the quality education of multilingual learners and their teachers. Overall, this work illustrates the manner in which current policies and practices are institutionalizing linguicism and racism and promoting inequitable outcomes for multilingual learners and their teachers.

\section{Theoretical Framework: Critical Race Theory (CRT)}

Critical race theory (CRT) was developed as a response to the stalled advances of the civil rights era in the United States during the mid-1970s and 
originated in the field of law to combat the lasting, institutionalized forms of racism that were becoming prominent (Delgado \& Stefancic, 2001). Though significant progress in improving racist issues across the nation had been made, racism persisted and largely became conceived as individual "prejudice based on skin color," a definition that ignores the systemic, institutional, and social practices of power and privilege distribution (Crenshaw, Gotanda, Peller, \& Thomas, 1995, p. Xv). In response, early CRT scholars called for expanding legal scholarship and activism to unmask the undermining systemic and institutional factors preventing the remedy of racial inequity (Tate, 1997).

This study draws methodologically on the CRT construct of "majoritarian stories." The overarching tenets of CRT centralize race; challenge meritocracy, objectivity, neutrality, and ahistoricsim; emphasize experiential knowledge; and support interdisciplinality. Majoritarian stories often stand in contrast to these tenets and are therefore challenged by CRT scholars. Love (2004) defines majoritarian stories as:

The description of events as told by members of dominant/majority groups, accompanied by the values and beliefs that justify the actions taken by dominants to insure their dominant position. The commonly accepted "history" of the United States is one such story.... Typically, majoritarian stories are constructed so that the responsibility for their own subordination falls on the subordinated people. (pp. 228-229)

Contemporary majoritarian stories often downplay the centrality of race and racism in social institutions like schools and promote deficit ideologies that blame social and educational inequities on non-dominant populations. These stories generally draw on a cultural deficit model and blame students for failing to assimilate to the dominant White, middle-class, monolingual culture that defines success in school (Solórzano \& Yosso, 2002).

The power that majoritarian stories have in affecting definitions of success and failure is further discussed by Gillborn (2005), who argues that majoritarian stories often come from an ahistorical perspective. He suggests that solutions to inequitable schooling outcomes for students will never be found through "common sense" stories that ignore existing structural and historical issues of power and domination. Solorzáno and Yosso (2002) make an important point about majoritarian stories saying, "Whether told by people of color or Whites, majoritarian stories are not often questioned because people do not see them as stories but as 'natural' parts of everyday life" (p. 28). The idea that majoritarian stories are largely "invisible" and that they are told by both people of color and those with White privilege is important to note for this study, which identifies and challenges a common majoritarian story about multilingual learners and demonstrates how it powerfully engulfs the policies and practices encountered and engaged in by a multilingual bi-racial teacher of multilingual learners.

Mitchell (2012) conducted a CRT analysis of $\sim 100$ conceptual, empirical, and policy research studies in order to identify the common majoritarian stories regarding the education of secondary multilingual learners and their teachers. 
Specifically, the stories identified are the following: there is no story about race, difference is deficit, meritocracy is appropriate, and English is all that matters. These stories about race, difference, meritocracy, and English all play out in research and classroom practice in complex and at times contradictory ways. However, their presence calls for increased attention and analysis. Therefore, this study attempts to illustrate the practical outcomes and impacts of the majoritarian story focusing on English in systems, policies, and practices at the classroom level to illustrate how such an emphasis on English is promoting institutionalized issues of racism and linguicism for secondary multilingual learners and their teachers.

\section{Research Design}

This study utilizes longitudinal qualitative data that were collected over several years for the Qualitative Case Studies (QCS) project ${ }^{1}$, which is one of six studies in an evidence portfolio created to investigate empirically various aspects and impacts of participation in a particular teacher education program. QCS is a longitudinal qualitative multiple case study (Stake, 2006) following teacher candidates through their teacher preparation experience into their first few years of teaching. I was a researcher in this larger project and personally collected the dataset described below.

Amanda Lee ${ }^{2}$, one of the participants in the QCS study, was selected for in-depth analysis for this research due to her personal commitments to equity and social justice as well as her life experiences as a bi-racial American and multilingual learner. She was further selected because through her teacher education experiences she met the criteria set forth by the state to teach multilingual learners in a Sheltered English Instruction (SEI) classroom. Additionally, once she became licensed, she took the state-mandated teacher licensure test that qualified her to receive an additional certification in English as a Second Language (ESL). Finally, Amanda was selected as a participant suitable for this analysis because she worked in an urban setting with a large population of multilingual learners and taught mainstream courses (i.e., not SEI or ESL courses). Therefore, Amanda's teaching context and teacher preparation background made her a suitable choice for in-depth exploration regarding how current systems, policies, and procedures play out at the classroom level for multilingual learners and their teachers. The following table describes the dataset collected over four years regarding Amanda's experiences, practices, and perceptions. 
Table 1. Four Years of Qualitative Data on Amanda Lee

\begin{tabular}{|c|c|c|}
\hline Data Source & Description & Totals \\
\hline $\begin{array}{l}\text { Teacher Candidate/New } \\
\text { Teacher Interviews }\end{array}$ & $\begin{array}{l}60-90 \text { minute interviews with Amanda over } 4 \\
\text { years (pre-service year and first } 3 \text { years of in- } \\
\text { service teaching). }\end{array}$ & 12 \\
\hline $\begin{array}{l}\text { Teacher Candidate/New } \\
\text { Teacher Observations }\end{array}$ & $\begin{array}{l}75-120 \text { minute observations of Amanda in pre- } \\
\text { and full-practicum classrooms as well as in first } \\
\text { and third year of teaching including copies of } \\
\text { assessment tasks and pupil work associated } \\
\text { with each observation. }\end{array}$ & 24 \\
\hline $\begin{array}{l}\text { Teacher Inquiry Project } \\
\text { and Other Teacher } \\
\text { Education Coursework }\end{array}$ & $\begin{array}{l}1 \text { Inquiry Project, plus } 3 \text { additional coursework } \\
\text { projects and } 6 \text { lesson plans/units created for } \\
\text { teacher education course assignments. }\end{array}$ & 10 \\
\hline Auxiliary Interviews & $\begin{array}{l}\text { 15-40 minute interviews conducted in spring of } \\
\text { case study teacher's pre-service year (with } \\
\text { cooperating teacher and university supervisor) } \\
\text { and spring of } 1^{\text {st }} \text { year (with an administrator, } \\
\text { mentor, and individual interviews with } 5 \text { bilingual } \\
\text { learners from two different classes as well as } \\
\text { two focus groups with those } 5 \text { students and one } \\
\text { focus group with } 10 \text { other students). }\end{array}$ & 12 \\
\hline $\begin{array}{l}\text { Classroom Assessment } \\
\text { Tasks/Samples of Pupil } \\
\text { Work }\end{array}$ & $\begin{array}{l}\text { Assessment tasks and samples of pupil work } \\
\text { from courses taught over the } \sim 4 \text { years of data } \\
\text { collection. }\end{array}$ & $\sim 200$ \\
\hline Fieldnotes & $\begin{array}{l}\text {-30 pages worth of fieldnotes taken over the } \\
\text { entire time of data collection }\end{array}$ & \\
\hline
\end{tabular}

The analysis of Amanda's data for this study was conducted with what Stevenson (2004) terms an "interpretive paradigm of inquiry," thus enabling an "ideological critique of dominant social patterns" that raises "consciousness about the conditions of oppression" (p. 45). While this work was not participatory or action oriented, through the analysis conducted various systemic issues in the education of secondary multilingual learners and their teachers are exposed and can now become the targets for transformative action.

Based on Yin's (2008) suggestion for multiple readings and "playing" with the data, I conducted what Stake (2000) calls an "instrumental case study," where a case is "examined mainly to provide insight into an issue or to redraw a generalization" (p. 437). He further explains:

The case is of secondary interest, it plays a supportive role, and it facilitates our understanding of something else. The case still is looked at in depth, its contexts scrutinized, its ordinary activities detailed, but all because this helps the researcher to pursue the external interest (p. 437). 
In the analysis of Amanda's case, my external interest focused on the systems and structures she was participating in and how those systems either supported or challenged the English-is-all-that-matters majoritarian story. Therefore, this analysis is an instrumental case study, in which Amanda's practice and perceptions over time are instrumental in illustrating the role that a majoritarian story emphasizing English can play in schooling contexts.

This study is the result of a comprehensive and deep engagement with all of the data across the entire four years of data collection. However, due to the research design, the bulk of the observations as well as the interviews with multilingual students took place during Amanda's first year of teaching. Therefore, the data discussed below are predominantly from that time period. While the closest examination of Amanda's practice occurred during her first year, a year that is often challenging for many new teachers, the systemic issues and problematic policies and practices influencing her education as well as that of her students remained consistent in her subsequent years of teaching.

\section{A Majoritarian Story: English Is All That Matters}

The English-is-all-that-matters majoritarian story is deeply ingrained in national narratives about immigrant assimilation and is told in various ways by teachers (Reeves, 2004), community members (Galindo, 2004), and policy makers (Olsen, 2009), from the perspective that immigrant populations resist learning English. Beyond the economic and political drive for Englishmonolingualism promoted by this majoritarian story, within the mythical narrative of immigration that accompanies it, the racialized nature of immigration into the United States is overlooked. At a time when the majority of immigrants are people of color (Awokoya \& Clark, 2008; Suárez-Orozco, Pimentel, \& Martin, 2009), even when immigrants do adopt the language, customs, values, and culture of mainstream America, they cannot disappear into it because of issues of race and White privilege (Suárez-Orozco \& Suárez-Orozco, 2001). Nevertheless, the majoritarian story of English-is-all-that-matters prevails and, as is illustrated in this study, dramatically affects the educational opportunities provided to the children of immigration as well as their teachers.

This "common sense" story demands the rapid acquisition of English, particularly in English-only contexts, so that multilingual learners can quickly be absorbed into regular district programs and become invisible in policy and practice. It promotes insufficient concepts of language acquisition and use. Additionally, it fundamentally positions multilingual learners as either problems to be solved or invisible once the problem of English deficiency has been deemed remedied. This study illustrates how the English-is-all-that-matters majoritarian story plays out in classroom practice and limits a quality education for multilingual learners and their teachers. 


\section{English-Only Instruction}

A significant component of the English-is-all-that-matters majoritarian story is that English is most efficiently and quickly learned in English-only contexts. This aspect of the majoritarian story fits within the predominant nativist (Galindo, 2011) immigrant narrative and actively diminishes the opportunities to use languages other than English in the public sphere. The common sentiment regarding English acquisition coming easily in English-only contexts was expressed by several teachers in the study of Walker, Shafer, and Liams (2004) who offered similar responses on the open-ended question section of their survey saying essentially, "My grandparents came to this country and did just fine learning English without any help." This perspective suggests that being around English is enough to learn it well and is the centerpiece to the English-is-all-thatmatters majoritarian story in terms of the promotion of English-only contexts.

The tangible power of the English-only component of the majoritarian story has been seen in the passage of California's Proposition 227, Arizona's Proposition 203, and Massachusetts's Question 2. These voter referenda significantly limit the use of native languages in classrooms and promote the idea that children quickly master new languages simply through being immersed in them. This stance towards English immersion and English-only instructional practices is occurring across the United States (Menken, 2010; Salazar, 2010), not just in the states with explicit anti-bilingual education policies.

The emphasis on English-only instruction played a significant role in Amanda's education as well as her multilingual students' education. Despite being multilingual herself, her educational experiences in the United States were in English-only instructional settings and promoted the dominant discourses around the hegemony of English. Additionally, she became a teacher in one of the states with an English-only mandate for instruction and insufficient requirements regarding the preparation of teachers of multilingual learners (Mitchell, 2010; Varnis, 2011). Her cooperating teacher during her pre-service year had no expertise or training regarding second language acquisition or effective approaches for building on multilingual learner assets and strengths in service of their high quality education. In fact, her cooperating teacher often engaged in racist and linguicist practices that Amanda regularly critiqued and made sincere attempts to disrupt.

In this powerful, English-only context, Amanda took the classes available to her to prepare herself to work effectively with multilingual learners and even prepared for and passed the state examination qualifying her as a teacher of multilingual learners. However, despite these efforts on her behalf and meeting the requirements set forth by the state, when I asked Amanda across multiple interviews about her teacher education experiences preparing her to work with multilingual learners and what she took away from those efforts, she consistently mentioned vocabulary instruction as a major emphasis. Amanda seemed to assume that language development and support for multilingual learners in the English-only context in which she operated was predominantly about vocabulary 
instruction. This assumption was supported through the practices I observed in her teaching over several years.

In an observation of Amanda's $10^{\text {th }}$ grade writing class, she began class with a "Do Now" activity in which students wrote vocabulary words down and created sentences with the new words in their notebooks. During the class period, they read aloud a text and came across the vocabulary word "belligerent." Amanda stopped the reading and asked the class what that word meant. No one knew. Amanda repeated the definition, pointed it out as a vocabulary word for the day, and then continued reading with the class. When they came across the next vocabulary word in the reading, "monotonous," Amanda did not ask students for the meaning or point it out as a vocabulary word; she simply said, "So he had no tone."

A few days later, I observed Amanda's $9^{\text {th }}$ grade writing class and saw a similar instance where the vocabulary work at the beginning of class did not appear to affect students' recognition of the new words when reading the text. While vocabulary instruction alone is insufficient to support strong levels of academic language development, it is an important component of that development (Brisk \& Harrington, 2007). However, despite Amanda's assumptions about the value of vocabulary instruction, it appears from the classroom observations I conducted and the results of student work on vocabulary tests (excerpts displayed below) that her students both needed the vocabulary instruction and could have benefitted from more in-depth work with the new words.

Below are the results of a vocabulary test that Amanda gave to her $9^{\text {th }}$ graders during her first year of teaching. The class was reading the book Monster and students were given the following directions and word bank:

Directions: Choose SIX vocabulary words from the Monster Word Bank and write a grammatically correct sentence, which shows me that you know the meaning of the word, for each one (1 pt each). You may only use the form of the word shown below.

MONSTER WORD BANK

Conspicuous (adj) Nonchalantly (adv) Orneriness (n)

Significance ( $n) \quad$ Riffle (v) Provocation (n) Gaping (adj)

$\begin{array}{llll}\text { Eulogy }(n) & \text { Scamper }(v) & \text { Beckon }(v) & \text { Mural }(n)\end{array}$

Below are the sentences provided by three $9^{\text {th }}$ grade multilingual learners in the course with the words they used from the word bank underlined.

Yoletta - Haitian Creole Speaking

1. I have a mural in my house in the living room.

2. My cuzin has a gaping between her to bottom teeth which looks nice on her. 
3. I Beckon to not tell a soul about the house party last Sat.

4. My auntie had a Provocation to drink whenever someone gets her mad.

5. My dad had a Riffle when he was in the millitary.

6. I have a significance of awards of good behavior.

\section{Maria - Spanish Speaking}

1. They artist painted a mural on the wall representing the peace in our neiborhood.

2. I riffled through the paper looking for somthing.

3. The mouse scampered through on room into another.

4. The door was gaping leting cold air into the room.

5. I beckoned your lieing about that story you told us.

6. He nonchalantly did something.

\section{Ramon - Spanish Speaking}

1. The happy dog scamper through the field.

2. There were plenty of mural at the museum.

3. The significance of basketball is teamwork.

4. In [Ms. Lee's] class I conspicuous to myself.

5. The teacher told me to riffle through all the pages.

6. When I was tired I sang nonchalantly.

As the work above illustrates, these three multilingual learners in Amanda's class did not yet have mastery over the vocabulary words, nor did they write grammatically correct sentences as requested by the quiz directions. From spelling issues, to subject-verb agreement, plurals, punctuation and capitalization, and parts of speech, these three multilingual learners displayed significant issues with English language forms and functions.

All three of these students were schooled in the United States and mostly in English-only schooling contexts their entire lives. All three of these multilingual learners were, according to Amanda, among the highest performing students in her class, and the school and district did not identify them as ELL or long-term ELL. I spoke with the students about their vocabulary work, particularly the quizzes, and Yoletta said, "It's easy for us." Maria agreed saying, "It's not very challenging." These sentiments are slightly problematic considering the vocabulary and linguistic issues present in the work displayed above. 
Unfortunately, the English-only focus of the schooling these students had received and were receiving in Amanda's classroom did not support strong levels of academic English proficiency. The English-is-all-that-matters majoritarian story that assumes being around English is enough to learn it well is not supported by the experiences of these students, nor by research (Crawford \& Krashen, 2007; Lucas \& Grinberg, 2008; Schleppegrell, 2004). However, it was the perspective of Amanda's mentor who casually commented that the "grammar will come," suggesting that teachers do not need to explicitly teach the features of academic English, yet it is apparent that explicit instruction around English forms and features would have greatly benefited these students in addition to engaging them in more impactful vocabulary work.

Schleppegrell (2004) discusses the connectedness of language and learning and argues that in order for students to be successful in school, they need to have understandings about the "linguistic choices that realize that context" (p. 22). Her work demonstrates how schools value the discourses of power while devaluing other ways of using language. Further, she argues that insufficient attention is paid to language forms and function in school and teacher education curricula. In a perfect description of Amanda's situation, Schleppegrell suggests that "even teachers who would like to draw students' attention to differences in text types and the linguistic choices that make one text more powerful than another lack tools for incorporating such an emphasis into classroom instruction" (p. 17). The language of schooling ends up being a "hidden curriculum" that limits opportunities for teachers and multilingual learners to achieve at high levels.

Effective bilingual education programs have been consistently shown to support student development of biliteracy, bilingualism, grade level content knowledge, and high levels of academic English (e.g., Brisk, 2006; Proctor, August, Carlo, \& Barr, 2010; Ramírez, Yuen, \& Ramey, 1991; Slavin, Madden, Calderón, Chamberlain, \& Hennessy, 2010). However, quality bilingual programs are not always available to all students in all languages and in all contexts. While that would be the ideal, students can maintain and expand in their multilingualism while developing high levels of academic English proficiency when their linguistic strengths are valued and built on in effective ways in instructional settings even when English is the dominant language of instruction. In a setting where English matters, but is not all that matters, student perspectives, linguistic backgrounds, and multiliteracies are valued, utilized, and built upon to help students gain access to different ways of being, knowing, and using language (Expósito, \& Favela, 2003; Fine, Jaffe-Walter, Pedraza, Futch, \& Stoudt, 2007; González, $1998,2001)$. In such a setting, students and teachers have ways of talking about language, deconstructing it, reconstructing it, and thinking deeply about meaning as well as the power and privilege associated with certain forms (Brisk \& Zisselsberger, 2011; de Oliveira \& Dodds, 2010; Fang \& Schleppegrell, 2010; Schleppegrell, 2010).

Therefore the English-is-all-that-matters majoritarian story with its emphasis on learning English in English-only contexts is limiting the opportunity 
for multilingual learners to develop high levels of proficiency in academic English, thus institutionalizing racism and linguicism. The irony of this majoritarian story that emphasizes English and fundamentally overlooks the importance of biliteracy, multilingualism, grade level content learning, as well as the development of critical perspectives and thinking skills, lies in that fact that while emphasizing English it is simultaneously limiting opportunities for multilingual learners to gain high levels of academic English proficiency.

\section{Limited Perspectives of What It Means to "Know" English}

Another substantial component of the English-is-all-that-matters majoritarian story posits that the outcome of a quality education for multilingual learners is the rapid acquisition of English in order for multillingual learners to be quickly absorbed into "the district's mainstream educational program" (MA DESE, 2003, p. 10). In this way, the majoritarian story positions multilingual learners as English-deficient and in need of English remediation. The purpose of instruction for multilingual learners focuses then on "catching-up" multilingual learners to their native speaking peers (MA DESE, 2008, p. 3). With such an instructional purpose, multilingual learners can often be viewed as only the responsibility of a few teachers (Walker, Shafer, \& Liams, 2004), and those teachers as well as their students may be substantially physically and socially marginalized (Heineke \& Cameron, 2011; Liggett, 2010).

However, in policy and practice, the concepts of speaking English and acquiring "a good working knowledge of English" (M.G.L.C. 71A§4) suggest a monolithic and simplistic picture of language acquisition and attainment that often pushes multilingual learners into mainstream classes before they have adequate levels of academic English to support their long-term success (Hakuta, 2011). The English-is-all-that-matters majoritarian story promotes a restricted concept of language proficiency and accuracy that dismisses the reality of the social and fluid nature of language as well as the inherent variation in language across differing contexts (i.e., written forms vs. oral, social language vs. academic) (García, 2009).

Further, unidimensional understandings of language use and acquisition, as critiqued by Stevens (2009), can overlook the multiliteracies multilingual learners often utilize both in and out of schooling contexts. Additionally, such concepts of success in terms of multilingual learner education can create students who are literate for schooling purposes, "but not for critically engaging with [their] life realities" (Stevens, 2009, p.7). The narrow conceptions of language use promoted by the English-is-all-that-matters majoritarian story limit the opportunities for multilingual learners and their teachers to engage with the critical multiliteracies necessary for success across various forums.

In the case of the majoritarian story of English-is-all-that-matters, it appears that English proficiency is determined at insufficient levels and is not supporting multilingual learner success in more complex academic contexts. As has been discussed and illustrated, it appears that multilingual learners may not 
be receiving the support they need to develop high levels of academic English proficiency.

The following is an excerpt of student work from one of Amanda's $10^{\text {th }}$ graders during her first year of teaching. This Latina bilingual learner, Ana, often talked about going to college and becoming a lawyer. In fact, when I saw Ana as a $12^{\text {th }}$ grader during an observation of Amanda's classes, she told me she had been accepted to and planned to attend a local four-year college. Except for her first year of schooling, Ana was educated entirely in the United States. She had long participated in mainstream, English-only classrooms and wrote the following as a revision of the first assignment she turned in to Amanda in their $10^{\text {th }}$ grade writing class.

I believe it is very important for kids to get an education but I don't think getting an education seems to be an important value o everyone in my community, because in my community people don't care about an education, people don't care about an education because all they want to do is smoke weed and hang out with their friends. My parents are a very impotant part of my life. My parents encourage me everyday, they tell me that without an education I cant get anywhere., they also show me examples of people who didn't get an education and that makes me realize that I am doing good by staying in school.

Ana's writing exposes substantial linguistic issues. Yet these linguistic issues were not confined to Ana's writing. All of the multilingual learners in my study wrote at insufficient levels for post-secondary educational success. It appears that their education in predominantly English-only contexts mixed with a limited notion of what it means to "know" English positioned these students to never receive the kind of linguistically responsive education necessary to support their long-term educational success (Lucas, 2011).

Considering Amanda's limited training and experience working with multilingual learners, as well as her school policy context where very few students were identified as "ELL" and the fact that no supports existed for multilingual learners at higher levels of English proficiency, it is not surprising that linguistically responsive instructional practices or classroom policies did not exist in Amanda's classroom. It appears that the school in general expected students to have already reached high enough levels of academic English proficiency that such targeted instruction would not be warranted. However, none of the multilingual learners in her classes utilized academic English at the level expected of native English peers at the same grade level. Yet, no school or classroom level policies or programs were targeted towards supporting these students' success. Their level of English proficiency was high enough no longer to receive targeted supports from the school, yet too low to be prepared for postsecondary success. Again, the English-is-all-that-matters majoritarian story is contradictory in nature as well as powerful in promoting institutional practices that limit the educational opportunities of multilingual learners, particularly in terms of academic English attainment. 


\section{Multilingual Learners Treated as Monolingual}

Another problematic feature of the English-is-all-that-matters majoritarian story is how it promotes a deficit perspective of multilingual learners and makes it difficult for educators and administrators to see the linguistic skills and strengths multilingual learners have. Positioning multilingual learners as merely deficient in English has been critiqued in various ways across the research literature. Valdés (1998), MacGregor-Mendoza (2000), and Gándara and Orfield (2012) discuss how language remediation can be utilized as a tool for segregation, creating a school within a school that marginalizes and limits academic growth opportunities. Wiley and Wright (2004) and Johnson (2005a, 2005b) show how the push for linguistic assimilation has generally been a method of social control through deculturation for the purpose of subordination and assimilation. Salazar (2010) shows how students themselves resist losing their linguistic and cultural heritage by disengaging in subtractive educational practices.

In contrast, many researchers (e.g., Harper, de Jong, \& Platt, 2008, Expósito \& Favela, 2003; Gándara \& Rumberger, 2009; Lucas, 2011) argue for an additive approach to teaching multilingual learners that builds on their strengths, assets, and linguistic abilities while also pushing both higher levels of English language development and academic content mastery. Simply put, a multilingual learner is much more than a student needing to quickly master English.

However, if a successful multilingual learner is a student who quickly acquires English and "catches up" to their peers, that student also becomes invisible in policy and practice, as they are then treated as if they are monolingual and monocultural. The "multiple worlds" the students engage in are ignored (Chhuon, Hudley, Brenner, \& Macias, 2010). Due to the power of the English-isall-that-matters majoritarian story, few multilingual learners, particularly those at higher levels of English proficiency, have access to policy, classroom practices, and assessment procedures that are responsive to their varying cultural and linguistic perspectives. In fact, Proctor and Silverman (2011) have shown that no effective measures even exist to analyze biliteracy and bilingualism, forcing researchers to "rely on monolingual measures of the two languages spoken by a bilingual individual" (p. 62). Stevens (2011) critiques this treatment of multilingual learners in simplistic and monolingual-focused perspectives, calling for educators generally to "have a more robust and rigorous way of knowing not just their students as learners, but knowing them as human beings in multiple contexts and understanding well those contexts" (p. 139). As Stevens points out, this means that educators need to build perspectives and methods of inquiry that will facilitate a more comprehensive understanding and acknowledgement of who students are and what they bring to the classroom. Unfortunately, the English-isall-that-matters majoritarian story limits such relationships and inquiries and institutionalizes discriminatory practices by positioning multilingual learners as either academic failures and English deficient or invisible in policy and practice. 
Amanda did not completely endorse the majoritarian story of English-is-allthat-matters. Amanda was multilingual herself and expressed a great love of languages. She enjoyed working with multilingual learners and did not stop students from using their native languages in social contexts in her classroom. However, despite these commitments, Amanda stated, "I don't think I treat my bilingual students any differently than my monolingual students." Such a statement does not mean that multilingual learners are entirely invisible in her classroom; however, through all of our conversations and my observations over four years, I did not find evidence that she designed instruction with multilingual learners specifically in mind. Such practices are consistent with other research about multilingual learners being invisible in that their multilingualism or varied assets and learning needs are not taken into account in mainstream classroom contexts (Reeves, 2004, 2009). Due to Amanda's teacher preparation, the context she was working in, and the ways in which she had been socialized as a new teacher, it is not surprising that she did not engage in a pedagogy that specifically had multilingual learners in mind. She was never given the tools to do so, nor did she work in an environment where such practice was fostered or expected.

However, there was one way in which Amanda admitted to treating her multilingual students differently from her monolingual learners. She mentioned that occasionally she is more lenient with grading for her multilingual learners. It is not uncommon for teachers to be lenient in grading multilingual learners (Bang, Suárez-Orozco, Pakes, \& O'Connor, 2009; Harklau, 2000). However, that is a problematic practice when it means that students do not get to learn what they need to learn due to a lack of teacher feedback or explicit instruction regarding both language and content learning.

With a few minor exceptions, in Amanda's classroom it appears that multilingual learners were treated as if they were monolingual. When this occurs, a significant portion of who multilingual learners are is left outside the classroom, and often an inadequate education is the result (Reeves, 2004; Salazar, 2010). It appears that over time Amanda drew more on her multilingual learners' strengths and expertise, because during my final observation of her class one of her students reflected on their work over the year and expressed an appreciation for the stories and insights his bilingual peers added to the class. While I never personally observed multilingual learners adding their unique expertise or perspectives into the classroom, it appears that Amanda utilized the unique knowledge her multilingual learners had about the world to support the learning and development of the entire class. From the comments of the students I observed, this appears to have been positive and positioned multilingual learners as assets in the classroom rather than completely invisible. However, it is not clear that Amanda engaged in teaching that was linguistically responsive (Lucas, 2011; Lucas, Villegas, \& Freedson-Gonzalez, 2008), critical of institutionalized linguicism (Liggett, 2010), or capable of pushing multilingual learners to higher levels of academic English proficiency or the development of critical multiliteracies (Stevens, 2009). 
Amanda became a teacher and taught in a system that focused on English-only instruction, maintained limited notions of what it means to "know" English, and positioned multilingual learners as predominantly invisible in her classroom because they were assumed to have reached a high enough level of English proficiency to be treated as if they were monolingual. Despite her personal commitments and efforts to work effectively with multilingual learners, the English-is-all-that-matters majoritarian story maintained substantial power over the learning opportunities that both she and her multilingual learners had. Similar to results of other studies (e.g., Chhuon et al., 2010; Salazar, 2010; Stevens, 2011), these findings demonstrate that the English-is-all-that-matters majoritarian story encourages limited notions of who multilingual learners are, masks the reality of the multiple worlds they engage in, and disguises what they are capable of accomplishing both in and outside of school. In order for committed, dedicated, and equity minded teachers, like Amanda, to meaningfully work with multilingual learners, the power of this majoritarian story must be diminished and actively countered.

\section{Conclusion: English is NOT All that Matters}

As described above, the English-is-all-that-matters majoritarian story plays a powerful role in the systems, policies, and practices that impact the education of secondary multilingual learners and their teachers. Despite a systemic and extensive emphasis on English acquisition, multilingual learners are not necessarily reaching sufficiently high levels of English proficiency to succeed in secondary and post-secondary contexts. English does matter, but it is not all that matters in supporting high levels of academic achievement and critical engagement among secondary multilingual learners. Under current policies and practices, students with an insufficient level of academic English proficiency become invisible and are educated as if they were monolingual English speakers, no longer deemed qualified to receive a linguistically responsive education.

The English-is-all-that-matters majoritarian story is currently dramatically limiting the educational opportunities of multilingual learners in terms of restricting the use of native languages in classrooms, labeling and essentializing students only according to their level of English proficiency, and overlooking their assets, strengths, and abilities in terms of what students bring to school communities. Policy makers, teacher educators, educational researchers, administrators, and classroom teachers need to critically examine their own relationship with this story. In what ways might our work be promoting it? Challenging it? How can this story be transformed to support high levels of student learning and achievement rather than essentializing and making multilingual learners invisible in policy and practice? Students need to be repositioned in the system as multilingual/bilingual rather than English deficient. Additionally, critical examinations of policy and practice at every level along the 
educational pipeline need to be conducted and the prominence of the majoritarian story that English-is-all-that-matters altered in order to dismantle the power of the racism and linguicism that limit the academic and language learning opportunities of secondary multilingual learners in schools across the United States today.

\section{Notes}

1. This research was supported in part by the "Teachers for a New Era" initiative, funded primarily by the Carnegie Corporation of New York. The Qualitative Case Study project was led by Marilyn Cochran-Smith and Patrick McQuillan. Researchers on the team included Karen Shakman, Lisa D'Souza, Cindy Jong, Joan Barnatt, Dianna Gahlsdorf Terrell, Ann Marie Gleeson, and Karen Lam.

2. All names in this study are pseudonyms.

\section{References}

Awokoya, J. T., \& Clark, C. (2008). Demystifying cultural theories and practices: Locating black immigrant experiences in teacher education research. Multicultural Education, 16(2), 49-58.

Bang, H. J., Suárez-Orozco, C., Pakes, J., \& O'Connor, E. (2009). The importance of homework in determining immigrant students' grades in schools in the USA context. Educational Research, 51(1), 1-25. doi:10.1080/00131880802704624

Brisk, M. E. (2006). Bilingual education: From compensatory to quality schooling. Mahwah, NJ: Lawrence Erlbaum Associates.

Brisk, M. E., \& Harrington, M. M. (2007). Literacy and bilingualism: A handbook for ALL teachers (2nd ed.). Mahwah, NJ: Lawrence Erlbaum Associates.

Brisk, M. E., \& Zisselsberger, M. (2011). "We've let them in on the secret": Using SFL theory to improve the teaching of writing to bilingual learners. In T. Lucas (Ed.), Teacher preparation for linguistically diverse classrooms. New York, NY: Routledge.

Chhuon, V., Hudley, C., Brenner, M. E., \& Macias, R. (2010). The multiple worlds of successful Cambodian American students. Urban Education, 45(1), 3057. doi:10.1177/0042085909352583

Crawford, J., \& Krashen, S. (2007). English learners in American classrooms: 101 questions, 101 answers. New York, NY: Scholastic 
Crenshaw, K. W., Gotanda, N., Peller, G., \& Thomas, K. (1995). Critical race theory: The key writings that formed the movement. New York, NY: The New Press.

de Oliveira, L. C., \& Dodds, K. N. (2010). Beyond general strategies for English language learners: Language dissection in science. Electronic Journal of Literacy Through Science, 9. Retrieved from http://ejlts.ucdavis.edu

Delgado, R., \& Stefancic, J. (2001). Critical race theory: An introduction. New York, NY: New York University Press.

Expósito, S., \& Favela, A. (2003). Reflective voices: Valuing immigrant students and teaching with ideological clarity. The Urban Review, 35(1), 73-91. doi:10.1023/A:1022597607497

Fang, Z., \& Schleppegrell, M. J. (2010). Disciplinary literacies across content areas: Supporting secondary reading through functional language analysis. Journal of Adolescent \& Adult Literacy, 53(7), 587-597. doi:10.1598/JAAL.53.7.

Fine, M., Jaffe-Walter, R., Pedraza, P., Futch, V., \& Stoudt, B. (2007). Swimming: On oxygen, resistance, and possibility for immigrant youth under siege. Anthropology and Education Quarterly, 38(1), 76-96.

Galindo, R. (2004). Newspaper editorial response to California's post-proposition 227 test scores. Journal of Latinos \& Education, 3(4), 227-250. doi:10.1207/s1532771xjle0304_3

Galindo, R. (2011). The nativistic legacy of the Americanization era in the education of Mexican immigrant students. Educational Studies, 47(4), 323-346. doi:10.1080/00131946.2011.589308

Gándara, P., \& Orfield, G. (2012). Segregating Arizona's English learners: A return to the "Mexican room"? Teachers College Press. Retrieved from http://www.tcrecord.org/content.asp?contentid $=16600$

Gándara, P., \& Rumberger, R. W. (2009). Immigration, language, and education: How does language policy structure opportunity? Teachers College Record, 111(3), 750-782.

García, O. (2009). Bilingual education in the 21st century: A global perspective. Malden, MA: Wiley-Blackwell.

Gillborn, D. (2005). Education policy as an act of white supremacy: Whiteness, critical race theory and education reform. Journal of Education Policy, 20(4), 485-505. doi:10.1080/02680930500132346

González, F. E. (1998). Formations of mexicananess: Trenza se identidades múltiples, growing up mexicana: Braids of multiple identities. Qualitative Studies in Education, 11(1), 81-102. doi:10.1080/09518399823690

González, F. E. (2001). Haciendo que hacer - cultivating a mestiza worldview and academic achievement: Braiding cultural knowledge into educational 
research, policy, practice. Qualitative Studies in Education, 14(5), 641656. doi:10.1080/0951839011005984

Hakuta, K. (2011). Educating language minority students and affirming their equal rights: Research and practical perspectives. Educational Researcher, 40(4), 163-174. doi:10.3102/0013189X11404943

Harklau, L. (2000). From the "good kids" to the "worst": Representations of English language learners across educational settings. TESOL Quarterly, 34(1), 35-67. doi:10.2307/3588096

Harper, C. A., de Jong, E. J., \& Platt, E. J. (2008). Marginalizing English as a second language expertise: The exclusionary consequence of No Child Left Behind. Language Policy, 7, 267-284. doi:10.1007/s10993-008-9102$\mathrm{y}$

Heineke, A. J., \& Cameron, Q. (2011). Closing the classroom door and the achievement gap: Teach for American alumni teachers' appropriation of Arizona language policy. Education and Urban Society. doi: $10.1177 / 0013124511413123$

Johnson, E. (2005a). Proposition 203: A critical metaphor analysis. Bilingual Research Journal, 29(1), 69-84. doi:10.1080/15235882.2005.10162824

Johnson, E. (2005b). WAR in the media: Metaphors, ideology, and the formation of language policy. Bilingual Research Journal, 29(3), 621-640. doi:10.1080/15235882.2005.10162855

Liggett, T. (2010). "A little bit marginalized": The structural marginalization of English language teachers in urban and rural public schools. Teaching Education, 21(3), 217-232. doi:10.1080/10476211003695514

Love, B. J. (2004). Brown plus 50 counter-storytelling: A critical race theory analysis of the "majoritarian achievement gap" story. Equity \& Excellence in Education, 37(3), 227-246. doi:10.1080/10665680490491597

Lucas, T. (2011). Teacher preparation for linguistically diverse classrooms: A resource for teacher educators. New York, NY: Routledge.

Lucas, T., \& Grinberg, J. (2008). Responding to the linguistic reality of mainstream classrooms: Preparing all teachers to teach English language learners. In M. Cochran-Smith, S. Feiman-Nemser, D. J. Mclntyre, \& K. E. Demers (Eds.), Handbook of research on teacher education: Enduring questions in changing contexts (pp. 606-636). New York, NY: Routledge/Taylor \& Francis Group and The Association of Teacher Educators.

Lucas, T., Villegas, A. M., \& Freedson-Gonzalez, M. (2008). Linguistically responsive teacher education: Preparing classroom teachers to teach English language learners. Journal of Teacher Education, 29(4), 361-373. doi:10.1177/002248710832211 
MacGregor-Mendoza, P. (2000). Aqui no se habla Español: Stories of linguistic repression in southwest schools. Bilingual Research Journal, 24(4), 355367. doi:10.1080/15235882.2000.10162772

Massachusetts Department of Education, (2003). Questions and answers regarding Chapter 71A: English language education in public schools. Retrieved from http://www.doe.mass.edu/ell/guidance_laws.html

Massachusetts Department of Elementary and Secondary Education. (2008). Coordinated program review procedures: School district information package--English learner education (ELE) in public schools Mass. Gen. Laws c. 71A. Retrieved from http://www.doe.mass.edu/ell/ guidance laws.html

Massachusetts General Laws. (1971). Chapter 71A - Transitional Bilingual Education. Retrieved from http://www.mass.gov/legis/laws/mgl/71a-1.htm

Menken, K. (2010). NCLB and English language learners: Challenges and consequences. Theory Into Practice, 49(2), 121-128. doi:10.1080/ 00405841003626619

Mitchell, K. (2010). Systemic inequities in the policy and practice of educating secondary bilingual learners and their teachers: A critical race theory analysis. (Doctoral Dissertation). Boston College, Chestnut Hill, MA

Mitchell, K. (2012). Race, difference, meritocracy, and English: Majoritarian stories in the education of secondary multilingual learners. Race Ethnicity and Education. doi:10.1080/13613324.2011.645569

Olsen, L. (2009). The role of advocacy in shaping immigrant education: A California case study. Teachers College Record, 111(3), 817-850.

Phillipson, R. (1992). Linguistic imperialism. New York, NY: Oxford University Press.

Proctor, C. P., August, D., Carlo, M., \& Barr, C. (2010). Language maintenance versus language of instruction: Spanish reading development among Latino and Latina bilingual learners. Journal of Social Issues, 66(1), 79-94.

Proctor, C. P., \& Silverman, R. D. (2011). Confounds in assessing the associations between biliteracy and English language proficiency. Educational Researcher, 40(2), 62-64. doi:10.3102/0013189X11403138

Ramírez, J. D., Yuen, S. D., \& Ramey, D. R. (1991). Final report: Longitudinal study of structured English immersion strategy, early-exit and late-exit transitional bilingual education programs for language-minority children Vols. I and II). San Mateo, CA: Aguirre International.

Reeves, J. (2004). "Like everybody else": Equalizing educational opportunity for English language learners. TESOL Quarterly, 38(1), 43-66. doi:10.2307/3588258

Reeves, J. (2009). Teacher investment in learner identity. Teaching \& Teacher Education, 25, 34-41. doi:10.1016/j.tate.2008.06.003 
Salazar, M. d. C. (2010). Pedagogical stances of high school ESL teachers: Huelgas in high school ESL classrooms. Bilingual Research Journal, 33, 111-124. doi:10.1080/15235881003733415

Schleppegrell, M. J. (2004). The language of school: A functional linguistics perspective. Mahwah, NJ: Lawrence Erlbaum Associates.

Schleppegrell, M. J. (2010). Functional grammar in the classroom. In M. Olofsson (Ed.), Symposium 2009. Genrer och funktionellt språk i teori och praktik (pp. 79-95). Stockholm: Stockholms universitets förlag.

Slavin, R. E., Madden, N., Calderón, M., Chamberlain, A., \& Hennessy, M. (2010). Reading and language outcomes of a five-year randomized evaluation of transitional bilingual education. Retrieved from http://ies.ed.gov/pubsearch/pubsinfo.asp?pubid=WWCQRRL0808

Solórzano, D. G., \& Yosso, T. J. (2002). Critical race methodology: Counterstorytelling as an analytical framework for education research. Qualitative Inquiry, 8(1), 23-44.

Stake, R. E. (2000). Case studies. In N. K. Denzin \& Y. S. Lincoln (Eds.), Handbook of Qualitative Research (2nd ed., pp. 435-454). Thousand Oaks, CA: Sage.

Stake, R. E. (2006). Multiple case study analysis. New York, NY: The Guilford Press.

Stevens, L. P. (2009). Maps to interrupt a pathology: Immigrant populations and education. Critical Inquiry in Language Studies, 6(1-2), 1-14. doi:10.1080/ 15427580802679245

Stevens, L. P. (2011). Literacy, capital, and education: A view from immigrant youth. Theory Into Practice, 50(2), 133-140. doi:10.1080/ 00405841.2011 .558441

Stevenson, R. B. (2004). Constructing knowledge of educational practices from case studies. Environmental Education Research, 10(1), 39-51. doi:10.1080/135046203200017369

Suárez-Orozco, C., Pimentel, A., \& Martin, M. (2009). The significance of relationships: Academic engagement and achievement among newcomer immigrant youth. Teachers College Record, 111(3), 712-749.

Suárez-Orozco, C., \& Suárez-Orozco, M. M. (2001). Children of immigration. Cambridge MA: Harvard University Press.

Tate, W. F. (1997). Critical race theory and education: History, theory, and implications. Review of Research in Education, 22, 195-247. doi:10.3102/0091732X022001195

Valdés, G. (1998). The world outside and inside schools: Language and immigrant children. Educational Researcher, 27(6), 4-18. 
Vaznis, J. (2011). US finds statewide problems in schools. Boston Globe,. Retrieved from http://articles.boston.com/2011-09-17/news/30169814 1 learners-teacher-training-school-districts

Walker, A., Shafer, J., \& Liams, M. (2004). "Not in my classroom": Teacher attitudes towards English language learners in the mainstream classroom. NABE Journal of Research and Practice, 2(1), 130-160.

Wiley, T. G., \& Wright, W. E. (2004). Against the undertow: Language-minority education policy and politics in the "age of accountability". Educational Policy, 18(1), 142-168. doi:10.1177/0895904803260030

Yin, R. K. (2008). Case study research: Design and methods (4th ed.). Thousand Oaks, CA: Sage. 